\title{
Effect of in-utero exposure to diethylstilboestrol on ontogeny of uterine glands in neonatal mice
}

\author{
R. Wordinger*, J. Nile and G. Stevens \\ Department of Anatomy and Cell Biology, The University of North Texas, Texas College of \\ Osteopathic Medicine, Fort Worth, TX 76107-2609, USA
}

\begin{abstract}
Summary. Pregnant CD-1 mice were injected with diethylstilboestrol $(10 \mu \mathrm{g} / \mathrm{kg}$ body weight) in $0.1 \mathrm{ml}$ maize oil, or maize oil alone, on Day 16 of gestation. Six experimental and 6 control female progeny were killed daily from birth until Day 7 and uterine tissues were examined by light microscopy. In-utero exposure to diethylstilboestrol resulted in hypertrophy of luminal epithelial cells and premature formation of uterine glands. The initial sign of uterine gland formation was invagination of the uterine surface epithelial cell layer into the underlying connective tissue stroma. A temporal difference occurred between control animals and those exposed to diethylstilboestrol: uterine gland formation first occurred in experimental progeny on Day 4, but not until Day 5 in control progeny. Uterine glands which extended deep into the connective tissue stroma to the myometrium were present in diethylstilboestrol-treated progeny by Day 7 , but remained in the superficial endometrial connective tissue stroma in control animals. The results indicate that prenatal exposure of mice to diethylstilboestrol causes uterine epithelial cell hypertrophy at birth and the premature formation of uterine glands during the first week of neonatal uterine development.
\end{abstract}

Keywords: uterine glands; development; diethylstilboestrol; mouse

\section{Introduction}

At birth, the mouse uterus is composed of undifferentiated mesenchyme connective tissue and simple columnar epithelial cells lining a uterine lumen (Brody \& Cunha, 1989). During the first 7 days of neonatal development the endometrium and the myometrium differentiate from the mesenchyme. The initiation of uterine gland formation is signalled by the invagination of the uterine epithelium into the developing connective tissue stroma (Brody \& Cunha, 1989). In rats, this process begins during the second week after birth and uterine glands extending to the myometrium are present by Days 10-14 (Branham et al., 1985).

Endogenous oestrogen is critical for initiation of normal postnatal uterine growth and differentiation. Neonatal ovariectomy (Baker \& Kragt, 1969; Sheehan et al., 1981) or the use of specific antiserum to oestradiol-17ß (Reiter et al., 1972) prevents formation of uterine glands. Endogenous ovarian oestrogen production in rats does not begin until about neonatal Day 9 (Dohler \& Wuttke, 1975). This is followed by increased oestrogen receptor concentrations and increased competence to respond to exogenous oestrogens (Somjen et al., 1973).

Neonatal tissue is an excellent system in which to investigate the action of prenatal exposure to oestrogen on cell differentiation and organ development. Alterations in the ontogeny of uterine glands in rats have been reported following neonatal exposure to oestradiol-17 $\beta$ (Sheehan et al., 1981; Branham et al., 1985), anti-oestrogens and diethylstilboestrol (Branham et al., 1988a, b, c). Although the mouse has been frequently used as an animal model to examine the effect of prenatal

*Author for correspondence. 
and neonatal exposure to oestrogens on the subsequent differentiation and development of the female reproductive tract (Bern et al., 1976; McLachlan et al., 1980; Ennis \& Davies 1982), less information is available concerning the normal ontogeny of uterine glands in mice and the influence of prenatal exposure to oestrogens on neonatal uterine gland ontogeny.

The objective of this experiment was to use light microscopy to (i) survey the normal developing neonatal mouse uterus from birth to 7 days of age and (ii) examine the effect of a single, prenatal exposure to diethylstilboestrol on the ontogeny of uterine glands in mice. The first 7 days of neonatal development are critical, since prenatal exposure to diethylstilboestrol causes a significant alteration in the dynamics of ovarian follicular development and thus may alter the ontogeny of uterine glands (Wordinger \& Derrenbacker, 1989).

\section{Materials and Methods}

Animals. CD-1 mice, 4-6 weeks old were purchased from Charles River Laboratories, Inc. (Wilmington, MA, USA). Female animals were housed in groups of 20 with food and water ad libitum, in a cycle of $14 \mathrm{~h}$ light to $10 \mathrm{~h}$ dark (lights on at $6: 00 \mathrm{~h}$ ) at $22^{\circ} \mathrm{C}$. Females were placed with individual males and inspected daily for a vaginal plug, which was considered Day 1 of pregnancy. Pregnant experimental mice were given a single subcutaneous injection of diethylstilboestrol (Sigma Chemical Co., St. Louis, MO, USA) at $10 \mu \mathrm{g} / \mathrm{kg}$ body weight administered in $0 \cdot 1 \mathrm{ml} \mathrm{maize} \mathrm{oil} \mathrm{on}$ Day 16 of gestation. Control animals received only $0.1 \mathrm{ml}$ maize oil on the analogous day of gestation.

All animals were allowed to give birth and 6 control and 6 diethylstilboestrol-exposed female progeny from 3 separate litters were killed daily from birth to postnatal Day 7 . Thus, uteri from 42 control and 42 diethylstilboestrolexposed animals were examined. At autopsy, the uterus was removed and prepared for light microscopy.

Tissue preparation for light microscopy. Uteri were dissected free under a dissecting microscope and fixed in $4 \%$ neutral buffered formalin for $48 \mathrm{~h}$ before being placed in a tissue processor for washing, dehydration and clearing. Tissues were embedded in a mixture of paraplast and paraffin wax $(1: 1 \mathrm{v} / \mathrm{v})$ and sectioned at $5 \mu \mathrm{m}$ on a rotary microtome. Sections were stained using a routine haematoxylin and eosin procedure and examined on a Zeiss Photo III microscope. Photomicrographs were taken using T-Max 100 (Kodak Inc.) black and white print film.

Quantitative estimation of uterine glands and epithelial cell height. Quantitative estimates in control and diethylstilboestrol-exposed animals were made by a revision of the serial sectioning technique of Pedersen \& Peters (1968). Three consecutive 5- $\mu \mathrm{m}$ sections were cut at 4 different levels in the uterus. Thus, 12 representative sections were used to obtain comparable values for the uterus. Data obtained in this manner are indicative and do not provide absolute numbers.

Uterine glands per uterine section. Glands were counted using the criteria of Branham et al. (1985): (i) a visible glandular lumen must be observed, (ii) the glandular lumen must be separated from the uterine lumen by connective tissue and (iii) epithelial cells must line the glandular lumen. The number of uterine glands per tissue section represents an average of counts since the number of glands in the proximal, middle or distal portions of the uterus does not differ significantly (Branham et al, , 1985).

Epithelial cell height. Measurements were obtained with the use of a calibrated eyepiece micrometer and $\times 100$ magnification and converted and reported in $\mu \mathrm{m}$.

Statistical analysis. All quantitative experimental data were compared with control values and differences analysed by using Student's $t$ test for significant differences between individual groups. Differences were considered statistically significant at $P<0.01$.

\section{Results}

\section{Uterine morphology}

At birth, the mouse uterus is relatively immature consisting of a lumen lined by simple columnar epithelial cells and differentiating mesenchyme connective tissue. The mesenchyme was broadly separated into three structurally distinct layers. By neonatal Day 4 the inner mesenchyme layer laying adjacent to the epithelial layer had developed into the endometrial connective tissue stroma (Fig. 1). The inner circular and outer longitudinal layers of the myometrium differentiated from the middle and outer mesenchyme. No pronounced changes in this morphology were observed during the first 4 days of development in control animals (Fig. 1). 


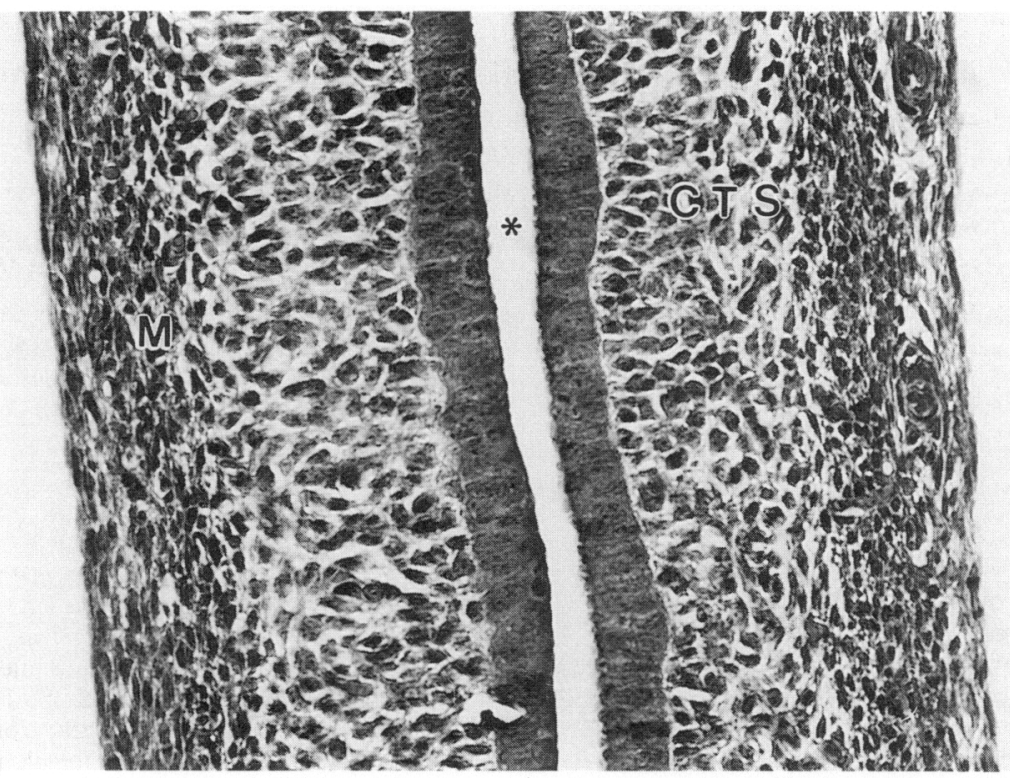

Fig. 1. Uterus of control mouse on neonatal Day 4. The mesenchyme has differentiated into the endometrial connective tissue stroma (CTS) and the myometrium (M). The uterine lumen $\left.{ }^{*}\right)$ is lined by a simple columnar epithelium. No uterine glands are present. Stained with haematoxylin and eosin; $\times 78$.

Invagination of the luminal epithelium into the differentiating endometrial connective tissue stroma was the initial sign of uterine gland formation (Fig. 2). This activity was first observed in control animals on Day 5 but occurred 24 h earlier in treated animals on Day 4 (Fig. 2). The treated animals seemed to have a greater degree of invagination along the length of the epithelial layer although this aspect was not quantified. Following the initial invagination of the luminal epithelium, uterine glands in cross section were observed within the superficial endometrium (Fig. 3). The developing uterine glands consisted of a simple columnar epithelium and were initially localized to the superficial connective tissue stroma. These glands were seen in cross section approximately $24 \mathrm{~h}$ after the initial invagination of the epithelial layer was observed. Thus, uterine glands appeared earlier in diethylstilboestrol-treated animals (Day 5) than in control animals (Day 6). There were more uterine glands in experimental than in control animals (Fig. 4).

By postnatal Day 7, uterine glands were seen in cross section lying deep in the endometrium adjacent to the myometrium in diethylstilboestrol-treated animals (Fig. 5), but they remained in the superficial connective tissue stroma in the control animals.

\section{Luminal epithelial cell height and uterine glands}

Exposure to diethylstilboestrol in utero resulted in luminal epithelium hypertrophy at birth as evidenced by greater epithelial cell height than in control animals (Table 1) on all the days it was examined. Epithelial cell heights gradually increased from birth until Day 7 in control animals, but remained high in the treated animals throughout the first week of neonatal development.

The number of uterine glands seen in cross section per microscope field from birth to Day 7 is shown in Table 2. Since serial histological section were not obtained, these results represent a relative estimate of uterine glands. No uterine glands were observed from birth to Day 4 in control or treated animals. However, cross sections of uterine glands were observed from Day 5 in treated animals. The number of uterine glands increased until Day 7. In control animals uterine glands were not observed until Day 6 and their numbers did not increase. 


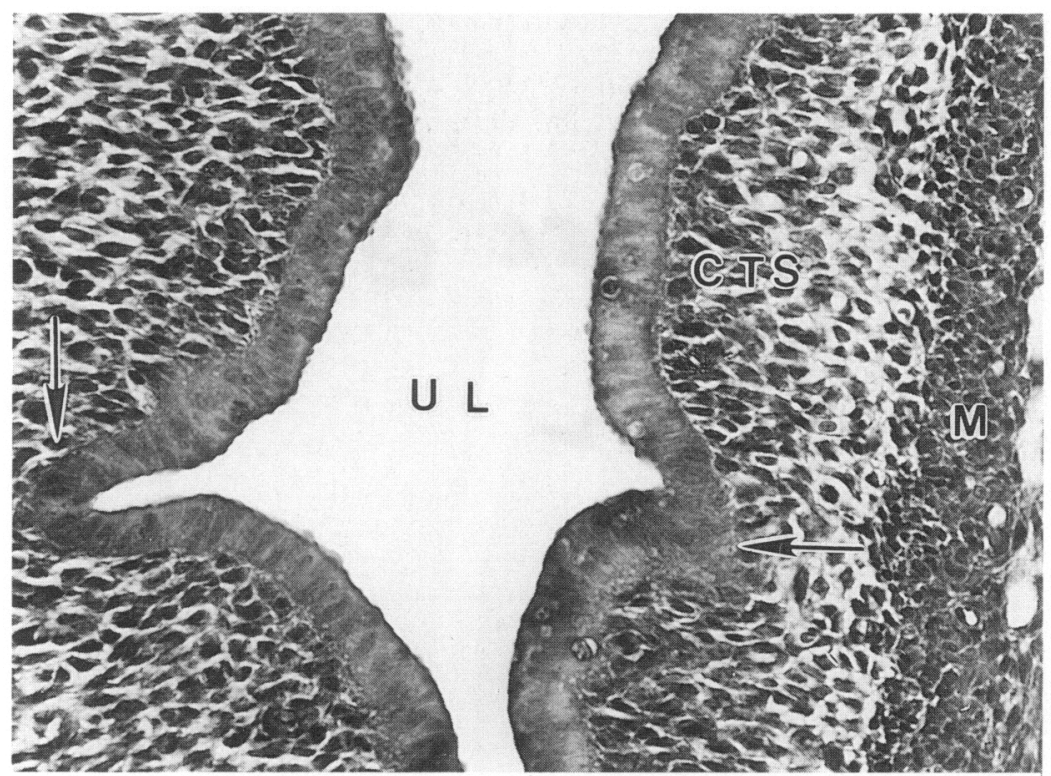

Fig. 2. Uterus of diethylstilboestrol-treated mouse on Day 4. Invagination of the uterine luminal epithelium (arrows) into the endometrial connective tissue stroma (CTS) has been initiated; uterine lumen (UL); myometrium (M). Stained with haematoxylin and $\operatorname{cosin} ; \times 80$.

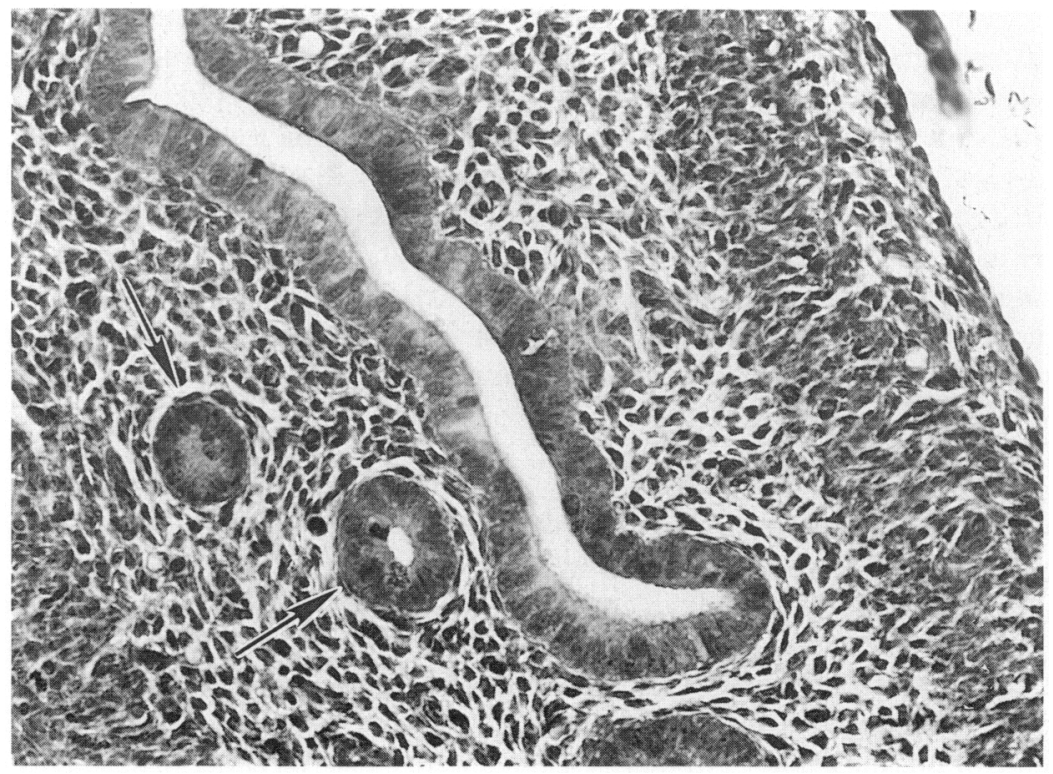

Fig. 3. Uterus of control mouse on neonatal Day 6. A few uterine glands (arrows) are forming in the superficial endometrial connective tissue stroma. Stained with haematoxylin and eosin; $\times 80$. 


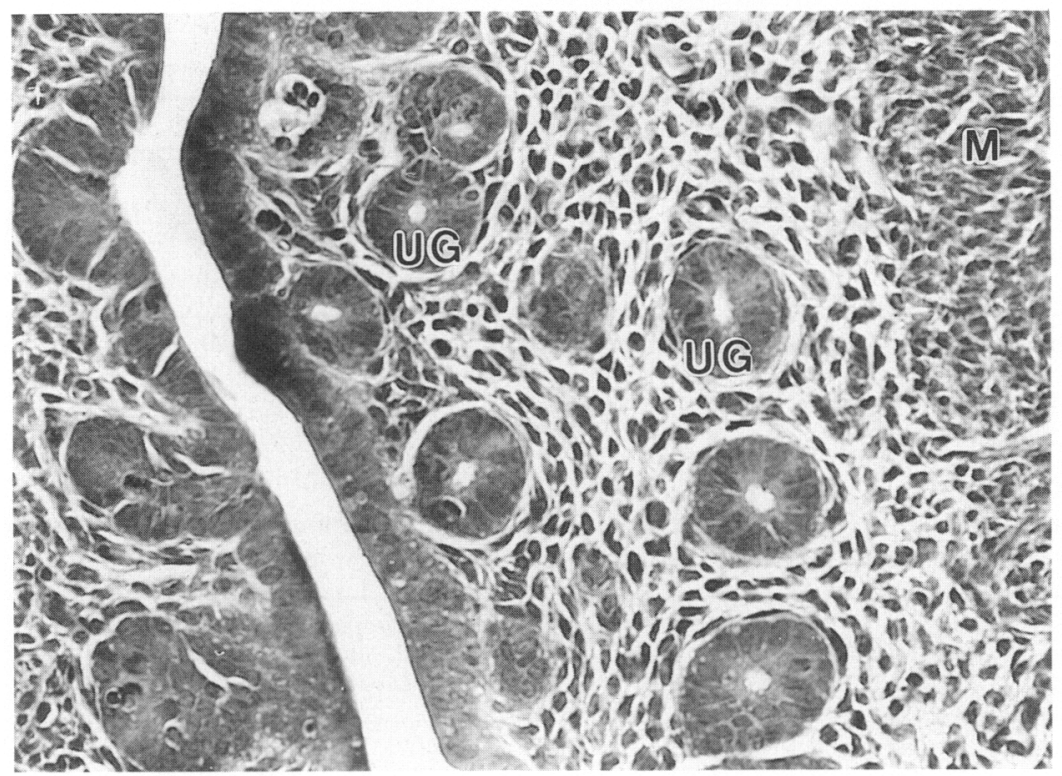

Fig. 4. Uterus of dicthylstilbocstrol-treated mouse on Day 6. Numerous cross sections of uterine glands ( $\mathrm{UG}$ ) are present in the superficial endometrial connective tissue stroma; myometrium $(\mathrm{M})$. Stained with haematoxylin and eosin; $\times 82$.

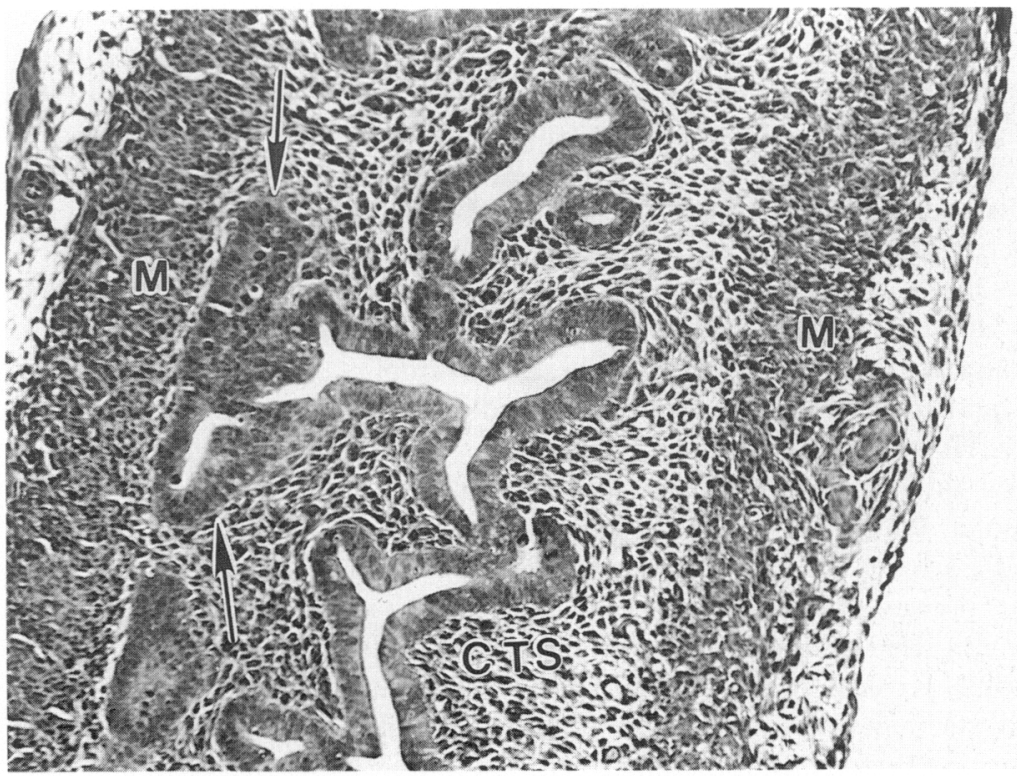

Fig. 5. Uterus of diethylstilboestrol-treated mouse on Day 7. Uterine glands (arrows) are present deep in the endometrial connective tissue stroma (CTS) adjacent to the myometrium. (M). The endometrial lumen is highly invaginated. Stained with haematoxylin and eosin; $\times 32$. 
Table 1. Uterine luminal epithelial cell heights $(\mu \mathrm{m})$ in control and diethylstilboestrol (DES)-treated mice from birth to Day 7

\begin{tabular}{|c|c|c|c|c|c|c|c|}
\hline \multirow[b]{2}{*}{ Group } & \multicolumn{7}{|c|}{ Days of postnatal development } \\
\hline & I & 2 & 3 & 4 & 5 & 6 & 7 \\
\hline $\begin{array}{l}\text { Control } \\
\text { DES }\end{array}$ & $\begin{array}{l}16 \cdot 97 \pm 0 \cdot 24 \\
20 \cdot 15 \pm 0 \cdot 40^{* *}\end{array}$ & $\begin{array}{l}18 \cdot 07 \pm 0 \cdot 32 \\
22 \cdot 20 \pm 0 \cdot 32^{* *}\end{array}$ & $\begin{array}{l}19 \cdot 39 \pm 0 \cdot 40 \\
22 \cdot 70 \pm 0 \cdot 35^{* *}\end{array}$ & $\begin{array}{l}20 \cdot 05 \pm 0.77 \\
22.57 \pm 0 \cdot 20^{* *}\end{array}$ & $\begin{array}{l}18 \cdot 48 \pm 0 \cdot 30 \\
23 \cdot 64 \pm 0 \cdot 30^{* *}\end{array}$ & $\begin{array}{l}20 \cdot 21 \pm 0.45 \\
22 \cdot 58 \pm 0 \cdot 30^{*}\end{array}$ & $\begin{array}{l}20 \cdot 40 \pm 0 \cdot 58 \\
22 \cdot 17 \pm 0 \cdot 10^{*}\end{array}$ \\
\hline
\end{tabular}

Values are means \pm s.e.m. Significantly different from control: ${ }^{*} P<0.01 ; * * P<001$

Table 2. Number of uterine glands seen in cross section per microscopic field in control and diethylstilboestrol (DES)-treated mice from birth to Day 7

\begin{tabular}{|c|c|c|c|c|c|c|c|}
\hline \multirow[b]{2}{*}{ Group } & \multicolumn{7}{|c|}{ Days of postnatal development } \\
\hline & 1 & 2 & 3 & 4 & 5 & 6 & 7 \\
\hline Control & $0 \cdot 00$ & 0.00 & $0 \cdot 00$ & $0 \cdot 00$ & $0 \cdot 00$ & $0.64 \pm 0.1$ & $0.63 \pm 0.1$ \\
\hline DES & 0.00 & 0.00 & 0.00 & 0.00 & $0.63 \pm 0.1^{* *}$ & $2 \cdot 25 \pm 0.2^{* *}$ & $2 \cdot 15 \pm 0 \cdot 2^{* *}$ \\
\hline
\end{tabular}

Values are means \pm s.e.m. Significantly different from control: ${ }^{* *} P<0.001$.

\section{Discussion}

Our results demonstrate that a single exposure to diethylstilboestrol in utero on Day 16 of gestation caused alterations in the normal differentiation of mouse uterus during the first 7 days of neonatal development. We observed transplacental stimulation by diethylstilboestrol, as hypertrophy of the endometrial epithelium at birth and premature development of uterine glands. This type of alteration has also been observed in guinea-pigs after prenatal exposure to diethylstilboestrol (Davies et al., 1986). There are several possible mechanisms by which diethylstilboestrol may enhance uterine differentiation.

Our results showed that, at birth, the mouse uterus is composed of undifferentiated mesenchyme connective tissue and simple columnar epithelial cells lining the uterine lumen. These results are similar to those of Brody \& Cunha (1989). By neonatal Day 4, the endometrium and the myometrium have differentiated from the mesenchyme. Earlier reports, using steroid autoradiography, demonstrated that both diethylstilboestrol (Stumpf et al., 1980) and oestradiol-17 $\beta$ (Cunha et al., 1982) bind to oestrogen receptors localized in nuclei of mesenchyme cells but not in the epithelial cells. However, morphogenesis and DNA synthesis was stimulated within the epithelial cell population in the neonate by endogenous oestrogens (Eide, 1975) and diethylstilboestrol (Bigsby \& Cunha, 1986). These paradoxical results were explained by the hypothesis that stromal cells produced a growth regulatory factor which acted on the epithelial cell population (Bigsby $\&$ Cunha, 1986). However, later reports have indicated that oestrogen receptor proteins may be present in the epithelial cell population but below the limits of detection and sensitivity of steroid autoradiography. Korach et al. (1988) have demonstrated oestrogen receptor protein in the epithelial and stromal cell fractions from 5-Day mouse uteri using SDS-polyacrylamide gel electrophoresis and Western Blot methods.

A second possible mechanism of action of diethylstilboestrol may be through altered ovarian development via the hypothalamo-hypophyseal system and not through direct action on uterine cells. The prenatal exposure of mice to diethylstilboestrol profoundly alters ovarian structure 
and function in neonatal and adult female progeny (Wordinger \& Highman, 1984; Wordinger \& Derrenbacker, 1989). Follicle maturation was advanced, mature follicles appearing during the first 7 days of neonatal development in diethylstilboestrol-exposed animals. It was suggested that diethylstilboestrol decreased the transit time between the various stages of follicle development by influencing the hypothalamo-hypophyseal axis. At birth, diethylstilboestrol-exposed progeny had significantly more Type $3 a$ ovarian follicles, and Types $3 \mathrm{~b}$ and 4 follicles appeared earlier than in control progeny. On Day 5 of neonatal ovarian development, a burst of ovarian follicular development has been reported (Wordinger \& Derrenbacker, 1989). Type 4 ovarian follicles with a developing theca interna are present as well as increased angiogenesis within the ovarian stroma.

It may be significant that the increase in ovarian follicle activity coincides in diethylstilboestrolexposed animals with the initial appearance of uterine glands. These morphological changes may signal altered endogenous ovarian steroid production which might influence uterine gland formation. The presence of follicles with a theca interna during the first week of life in diethylstilboestrolexposed animals may alter the endocrine profile by increasing oestrogen concentrations which could have a secondary effect on the immature reproductive tract. The concentration of endogenous oestrogen produced could be higher and consequently not totally bound by circulating serum $\alpha$-foetoprotein thus becoming available to the target mesenchyme cells. Korach et al. (1988) demonstrated that oestrogen receptor protein expression is increased by treatment with diethylstilboestrol. This would provide a mechanism by which the oestrogen receptor would be present in epithelial cells prematurely and the continued exposure of foetal or neonatal tissues to endogenous or exogenous oestrogens would result in prolonged oestrogen stimulation and subsequent toxicity of the reproductive tract.

In conclusion, we have demonstrated a transplacental effect of diethylstilboestrol on the developing uterus. Prenatal exposure to diethylstilboestrol caused uterine epithelial cell hypertrophy at birth and the premature formation of uterine glands. The mechanism of action of diethylstilboestrol is unresolved, but may involve direct stimulation via oestrogen receptors, secondary stimulation via uterine-specific growth regulatory factors or an alteration in ovarian development leading to altered concentrations of endogenous oestrogens.

This study was supported in part by the Summer Science Research Program for Medical Students Grant No. 8-89-27 from the March of Dimes Birth Defects Foundation. We thank Ms Anne-Marie Brun-Zinkernagel for excellent photographic assistance.

\section{References}

Baker, F.D. \& Kragt, C.L. (1969) Maturation of the hypothalamic-pituitary-gonadal negative feedback's system. Endocrinology 85, 522-527.

Bern, H.A., Jones, L.A., Mills, K.T., Kohrman, A. \& Mori, T. (1976) Use of the neonatal mouse in studying long-term effects of early exposure to hormones and other agents. J. Toxicol environ. Health 1, $103-116$.

Bigsby, R.M. \& Cunha, G.R. (1986) Estrogen stimulation of deoxyribonucleic acid synthesis in uterine epithelial cells which lack estrogen receptors. Endocrinology 119, 390-396.

Branham, W.S., Sheehan, D.M., Zehr, D.R., Ridlon, E. \& Nelson, C.J. (1985) The postnatal ontogeny of rat uterine glands and age-related effects of oestradiol17ß. Endocrinology 117, 2229-2237.

Branham, W.S., Zehr, D.R., Chen, J.J. \& Sheehan, D.M. (1988a) Alterations in developing rat uterine cell populations after neonatal exposure to estrogens and anti-estrogens. Teratology 38, 271-279.
Branham, W.S., Zehr, D.R., Chen, J.J. \& Sheehan, D.M. (1988b) Postnatal uterine development in the rat: Estrogen and anti-estrogen effects on luminal epithelium. Teratology 38, 29-36.

Branham, W.S., Zehr, D.R., Chen, J.J. \& Sheehan, D.M. (1988c) Uterine abnormalities in rats exposed neonatally to diethylstilboestrol, ethynylestradiol, or clomiphene citrate. Toxicology 51, 201-212.

Brody, J.R. \& Cunha, G.R. (1989) Histologic, morphometric, and immunocytochemical analysis of myometrial development in rats and mice: I. Normal development. Am. J. Anat. 186, 1-20.

Cunha, G.R., Shannon, J.M., Vanderslice, K.D., Sekkingstad, M. \& Roboy, S.F. (1982) Autoradiographic analysis of nuclear estrogen binding sites during postnatal development of the genital tract of female mice. J. Steroid Biochem. 17, 281-286.

Davies, J., Russell, M. \& Davenport, G.R. (1985) Effects of maternal administration of diethylstilboestrol and 
oestradiol on the newborn guinea pig. Acta anat. 122, $39-61$.

Dohler, K.D. \& Wuttke, W. (1975) Changes with age in levels of serum gonadotropins, prolactin, and gonadal steroids in prepubertal male and female rats. Endocrinology 97, 898-907.

Eide, A. (1975) The effect of oestradiol on DNA synthesis in the neonatal mouse uterus and cervix. Cell Tissue Res. 156, 551-555.

Ennis, B.W. \& Davies, J. (1982) Reproductive tract abnormalities in rats treated neonatally with diethylstilboestrol. Am. J. Anat. 164, 145-154.

Korach, K.S., Horigome, T., Tomooka, Y., Yamashita, S., Newbold, R.R. \& McLachlan, J.A. (1988) Immunodetection of estrogen receptor in epithelial and stromal tissues of neonatal mouse uterus. Proc. natnl. Acad. Sci. U.S.A. 85, $3334-3337$.

McLachlan, J.A., Newbold, R.R. \& Bullock, B.C. (1980) Long-term effects on the female mouse genital tract associated with prenatal exposure to diethylstilboestrol. Cancer Res. 40, 3988-3999.

Pedersen, T. \& Peters, H. (1968) Proposal for a classification of oocytes and follicles in the mouse ovary. $J$. Reprod. Fert. 17, 555-557.
Reiter, E.O., Goldenberg, R.L., Vaitukaitis, J.L. \& Ross, G.T. (1972) A role for endogenous estrogen in ovarian development in the neonatal rat. Endocrinology 91, 1537-1539.

Sheehan, D.M., Branham, W.S., Medlock, K.L., Olson, M.E. \& Zehr, D.R. (1981) Uterine responses to oestradiol in the neonatal rat. Endocrinology 109, 76-82.

Somjen, D., Kaye, A.M. \& Linder, H.R. (1973) Postnatal development of uterine response to oestradiol-17 $\beta$ in the rat. Dev. Biol. 31, 409-412.

Stumpf, W.E., Narbaitz, R. \& Sar, M. (1980) Estrogen receptors in the fetal mouse. J. Steroid Biochem. 12, 55-64.

Wordinger, R.J. \& Derrenbacker, J. (1989) In utero exposure of mice to diethylstilboestrol alters neonatal ovarian follicle growth and development. Acta anat. $134,312-318$.

Wordinger, R.J. \& Highman, B. (1984) Histology and ultrastructure of the adult mouse ovary following a single prenatal exposure to diethylstilboestrol. Virchows Arch. B. Zellpath. 45, 241-254.

Received 8 August 1990 